\title{
R/Avr gene expression study of Rpi-vnt1.1 transgenic potato resistant to the Phytophthora infestans clonal lineage EC-1
}

\author{
Maria Lupe Roman ${ }^{1,4} \cdot$ Myriam Izarra $^{1}$ Hannele Lindqvist-Kreuze ${ }^{1}$. \\ Cristina Rivera $^{1} \cdot$ Soledad Gamboa $^{1} \cdot$ Jose Carlos Tovar $^{1,5} \cdot$ Gregory A. Forbes $^{2} \cdot$ \\ Jan F. Kreuze ${ }^{1} \cdot$ Marc Ghislain $^{3}$ (1)
}

Received: 21 May 2017 / Accepted: 13 July 2017 / Published online: 17 July 2017

(C) The Author(s) 2017. This article is an open access publication

\begin{abstract}
The Avr avirulence gene of Phytophthora infestans and $R$ gene of the potato are the genetic components of the gene-for-gene interaction resulting in host plant resistance. This effector-triggered immunity has been recently exploited to generate extreme resistance to late blight in potato by genetic engineering. The choice of the $R$ genes, their number forming a $R$ gene stack, and the pathogen Avr gene diversity will likely determine how long this extreme resistance will last. Here, we report on a comparative study on the Rpi-vnt1.1 gene which originated from Solanum venturii, and was introduced in the potato variety 'Desiree' by genetic transformation, and the Avr-vntl gene from two isolates of the EC-1 lineage of $P$. infestans. EC-1 was reported previously as not expressing the Avr-vnt 1 gene and, therefore, being virulent on Rpi-vnt1.1 transgenic plants. Unexpectedly, whole-plant resistance assays identified 5 out of 52 transgenic events as resistant to two isolates of P. infestans, POX067 and POX109, belonging to the EC-1 lineage. We demonstrated that in both isolates, the Avr-vnt1.l gene was expressed at a low level. Expression of
\end{abstract}

Communicated by Jaqueline M. Nugent.

Marc Ghislain

m.ghislain@cgiar.org

International Potato Center, P.O. Box 1558, Lima 12, Peru

2 International Potato Center, ICRAF - Kunming Institute of Botany (KIB), Heilongtan, Kunming 650204, China

3 International Potato Center, P.O. Box 25171, Nairobi 00603 , Kenya

4 Present Address: Universidad Nacional Agraria La Molina, Lima, Peru

5 Present Address: 975 North Warson Road, St. Louis, MO 63132, USA the Rpi-vnt1.1 gene was shown to be rapidly increased by two-fold and subsequently to have steady state expression for at least 5 days after the inoculation. The Rpi-vnt1.1 gene in addition to other $R$ genes as a stack in farmers' preferred varieties will confer extreme resistance to late blight disease and rotations of plants with different $R$-gene-stack in time is likely to last longer than plants with single $R$ gene.

Keywords Late blight resistance $\cdot$ Transgenic potato . Rpi-vnt1.1 gene $\cdot$ Durable resistance $\cdot$ Resistance management

\section{Introduction}

The potato has been domesticated in South America from wild tuber-bearing species and has today a large diversity of cultivated forms in the high Andes (Spooner et al. 2010). The potato, introduced in the sixteenth century to the old world, is estimated to have contributed to approximately one-quarter of the population growth in the old world between 1700 and 1900 (Nunn and Qian 2011). Currently, its annual production places the potato as the fourth crop worldwide and third as a food crop (FAO 2014; Haverkort and Struik 2015). The crop is a staple for millions of people but also an important source of income for smallscale farmers in low and middle-low income countries. The tubers provide carbohydrate with little fat, low amounts of good quality proteins, high concentrations of vitamin $\mathrm{C}$ and several B vitamins and potassium (Camire et al. 2009).

Potato yields have been on the rise in the developed world but have failed to increase substantially in lowincome economies. Requiring relatively high inputs, good technical knowledge for proper crop management, the potato seed systems in these countries remain weak and 
inefficient and are responsible for at least half of the yield gap (Haverkort and Struik 2015). The second half is attributed to losses due to diseases with the most severe and ubiquitous being late blight (LB) caused by the oomycete Phytophthora infestans (Fry 2008). The cost of the disease, considering both chemical control and yield losses, was estimated globally at $€ 5.2$ billion per year (Haverkort et al. 2009).

LB is controlled primarily by application of fungicides and this can generate a negative impact on the environment and human health though this is considered less severe than that caused by herbicides and insecticides (Haverkort et al. 2008). Further, excessive and improper use of chemical pesticides, can contribute the emergence of fungicideresistant strains complicating the disease control (Fry et al. 2015).

Genetic improvement to enhance resistance to LB has been a continual breeding objective, including the introgression of resistance genes from wild relatives. While some varieties have been developed with intermediate levels of resistance that appears to be stable, to our knowledge extreme resistance, characterizing many varieties when they are released, has always been short-lived. New strains of the pathogen were rapidly appearing and able to overcome these highly resistant potato varieties. The introgression of $R$ genes from the wild species Solanum demissum was eventually abandoned by potato breeders due to rapid breakdown of the resistance. However, the isolation of more $R$ genes from various wild species at the turn of this century rekindled the interest in the use of $R$ genes in potato varietal improvement. The first of these Rpi genes (resistance to P. infestans) was isolated from Solanum bulbocastanum, and few years later from many more wild species (Rodewald and Trognitz 2013). Virulence to $R 8$ and $R 9$ genes from $S$. demissum were unfrequently found in the pathogen populations and DNA markers associated with $R 8$ and $R 3 b$ genes from $S$. demissum are being used in breeding again. Another approach has been to introduce these via genetic transfer directly into existing varieties that are preferred by farmers (Haverkort et al. 2009).

The Rpi-vnt1.1 gene was isolated from Solanum venturii and shown to confer resistance to a wide range of $P$. infestans strains but it was not resistant to a strain from Ecuador belonging to the EC-1 clonal lineage, referred to hereafter as EC-1 (Foster et al. 2009; Pel et al. 2009; Pel 2010). The efficacy of the Rpi-vnt1.1 gene was demonstrated in 3 years with limited field trials in the UK where the transgenic potatoes with the Rpi-vntl.l gene were shown to have acquired resistance to LB disease (Jones et al. 2014). Recently, new transgenic potato varieties have been developed by Simplot which also contain the Rpivnt1.1 gene and are in the process of being released (Clark et al. 2014). The resistance proteins coded by the $R$ genes recognize either directly or indirectly specific effector proteins of the pathogen, resulting in hypersensitive response that kills the plant cells where the pathogen has gained entry. This resistance system is referred to as effector-triggered immunity (ETI) and the effectors to avirulent (AVR) proteins (Jones and Dangl 2006). In potato, P. infestans interactions involving $R$ gene and $A v r$ gene pairs have been identified and are the base of a new genetic improvement strategy referred to as effector-assisted breeding (Vleeshouwers et al. 2011). Overcoming host resistance and gain of virulence by $P$. infestans has been shown to happen through allelic variants of the Avr gene but also due to change in gene copy number or inactivation of genes through transcriptional gene silencing. Gain of virulence resulting from $A v r$ gene transcript differences has been described for the Avr2 and Avr-vntl genes in P. infestans (Gilroy et al. 2011; Pel 2010). Gene silencing of effector genes to gain virulence is found in other oomycete pathogens such as Phytophthora sojae (Qutob et al. 2009, 2013; Vetukuri et al. 2013; Na et al. 2014).

The stability over time of resistance mediated by the Rpi-vnt1.1 gene once introduced into a potato variety will depend on the ability of $P$. infestans to decrease the expression of the Avr-vnt1 gene to levels undetectable by the cognate $R$ gene. As previously noted, one isolate of the EC-1 clonal lineage of $P$. infestans that is abundant in in Peru, Ecuador, Colombia and Venezuela (Forbes et al. 1997, 1998; Perez et al. 2001; Delgado et al. 2013) was able to overcome the resistance provided by Rpi-vnt1.1 and that its Avr-vntl gene was not expressed or was silenced (Foster et al. 2009; Pel et al. 2009; Pel 2010).

In the present study, we introduced the Rpi-vnt1.1 gene from Solanum venturii by Agrobacterium-mediated genetic transformation into the potato variety 'Desiree' to obtain potato plants resistant to $P$. infestans. We tested the transgenic plants bearing the Rpi-vntl.1 gene for resistance against two $P$. infestans EC-1 isolates endemic to Peru and studied the expression of Avr-vntl in these isolates during infection. These Peruvian isolates pertain to the EC-1 clonal lineage that is typically highly variable in virulence of which one isolate from Ecuador has been described previously as overcoming resistance mediated by the Rpivnt1.1 gene.

\section{Materials and methods}

\section{Plant transformation vector and bacterial strains}

The DNA sequence of the Rpi-vnt1.1 gene of $4310 \mathrm{bp}$ (GenBank accession FJ423044.1) was chemically synthesized and cloned into the vector pUC57 with additional $X m a \mathrm{I}$ restriction sites by GenScript Corp. (New Jersey 
USA). This DNA was cloned from $S$. venturii and contains the native promoter and transcript termination sequences flanking a coding sequence without intron. The XmaI fragment was sub-cloned into a dephosphorylated XmaI restricted pCAMBIA2300 plant transformation binary vector. The resulting gene construct, referred to as pCIP93, bears the Rpi-vntl.1 gene and the nptII gene for kanamycin resistance between the right and left borders of its T-DNA (Fig. 1). pCIP93 was transferred by electroporation into the Agrobacterium tumefaciens hypervirulent strain EHA105 (Hood et al. 1993).

\section{Pathogen isolates}

Highly pathogenic $P$. infestans isolates POX067 and POX109, belonging to the clonal lineage EC-1 of the A1 mating type (Villamon et al. 2005), were retrieved from cryo-storage. The frozen tubes were briefly thawed under running tap water and a sporangial suspension from each tube was inoculated on tuber slices of a susceptible potato cultivar to induce sporulation. The potato slices were incubated for 12 days at $15-18^{\circ} \mathrm{C}$ with a 12 -h light regime, after which the sporangia were collected and used to make suspensions of 3000 sporangia/mL of sterile, distilled water for inoculation.

\section{Genetic transformation of potato}

We used agrobacterium-mediated transformation of internodes followed by direct organogenesis as described by Medina-Bolívar and Cramer (2004), with modifications for Solanum tuberosum var. 'Desiree'. Internodes of 4-week old in vitro propagated plantlets were cut with a blade covered with the A. tumefaciens strain bearing pCIP93. The bacteria were grown on semisolid medium Lysogeny broth (LB) supplemented with $100 \mathrm{mg} / \mathrm{L}$ kanamycin at $28^{\circ} \mathrm{C}$ for $48 \mathrm{~h}$. The infected internodes were then placed on co-culture semisolid medium $(4.3 \mathrm{~g} / \mathrm{L}$ salt Murashige and Skoog, $25 \mathrm{~g} / \mathrm{L}$ sucrose, $30 \mathrm{mg} / \mathrm{L}$ acetosyringone, and $2 \mathrm{~g} / \mathrm{L}$ Gelrite, $\mathrm{pH} 5.6$ ) for $24 \mathrm{~h}$ in dark at $18-22^{\circ} \mathrm{C}$. Then, infected internodes were transferred to the selective regeneration medium $(4.3 \mathrm{~g} / \mathrm{L}$ salt Murashige and Skoog, $20 \mathrm{~g} / \mathrm{L}$ sucrose, $0.02 \mathrm{mg} / \mathrm{L}$ of gibberellic acid, $0.02 \mathrm{mg} / \mathrm{L}$ naphthalene acetic acid, $2 \mathrm{mg} / \mathrm{L}$ zeatin riboside, $100 \mathrm{mg} / \mathrm{L}$ kanamycin, $250 \mathrm{mg} / \mathrm{L}$ carbenicillin, $2 \mathrm{~g} / \mathrm{L}$ Gelrite, $\mathrm{pH}$ 5.6). Explants were changed to fresh medium every 15 days under in vitro propagation conditions. After 6 weeks, shoots of approximately $1 \mathrm{~cm}$ were transferred to propagation medium $(4.3 \mathrm{~g} / \mathrm{L}$ MS salts, $0.12 \mathrm{~g} / \mathrm{L}$ thiamine, $0.6 \mathrm{~g} / \mathrm{L}$ glycine, $0.15 \mathrm{~g} / \mathrm{L}$ nicotinic acid, $0.15 \mathrm{~g} / \mathrm{L}$ pyridoxine, $0.02 \mathrm{~g} / \mathrm{L}$ gibberellic acid, $25 \mathrm{~g} / \mathrm{L}$ sucrose, $2 \mathrm{~g} / \mathrm{L}$ Gelrite, $\mathrm{pH}$ 5.6) with $250 \mathrm{mg} / \mathrm{L}$ of carbenicillin. To avoid obtaining identical transgenic events, only one shoot per infected internode was harvested. To avoid false kanamycin resistant regenerants, calli were induced from leaf segments of the putative transgenic plantlets and cultured for 4 weeks on a highly selective medium $(4.3 \mathrm{~g} / \mathrm{L}$ salt Murashige and Skoog, $20 \mathrm{~g} / \mathrm{L}$ sucrose, $20 \mathrm{~g} / \mathrm{L}$ mannitol, $0.5 \mathrm{~g} / \mathrm{L}$ 2-(N-Morpholino) ethanesulfonic acid, $0.5 \mathrm{~g} / \mathrm{L}$ polyvinylpyrrolidone, $0.2 \mathrm{~g} / \mathrm{L}$ glutamine, $0.04 \mathrm{~g} / \mathrm{L}$ adenine sulfate, $1 \mathrm{~mL} / \mathrm{L}$ of vitamins GAP, $1 \mathrm{mg} / \mathrm{L}$ naphthalene acetic acid, $0.1 \mathrm{mg} / \mathrm{L}$ 6-Bencyl-aminopurine, $200 \mathrm{mg} / \mathrm{L}$ kanamycin, and $2 \mathrm{~g} / \mathrm{L}$ Gelrite, $\mathrm{pH}$ 5.6) under in vitro propagation conditions. Plantlets that did not form calli were deemed false kanamycin resistant regenerants and discarded.

\section{Transgenic event characterization}

Genomic DNA was extracted from $50 \mathrm{mg}$ of leaves from putative transgenic plantlets resistant to kanamycin and untransformed controls as described by Doyle and Doyle

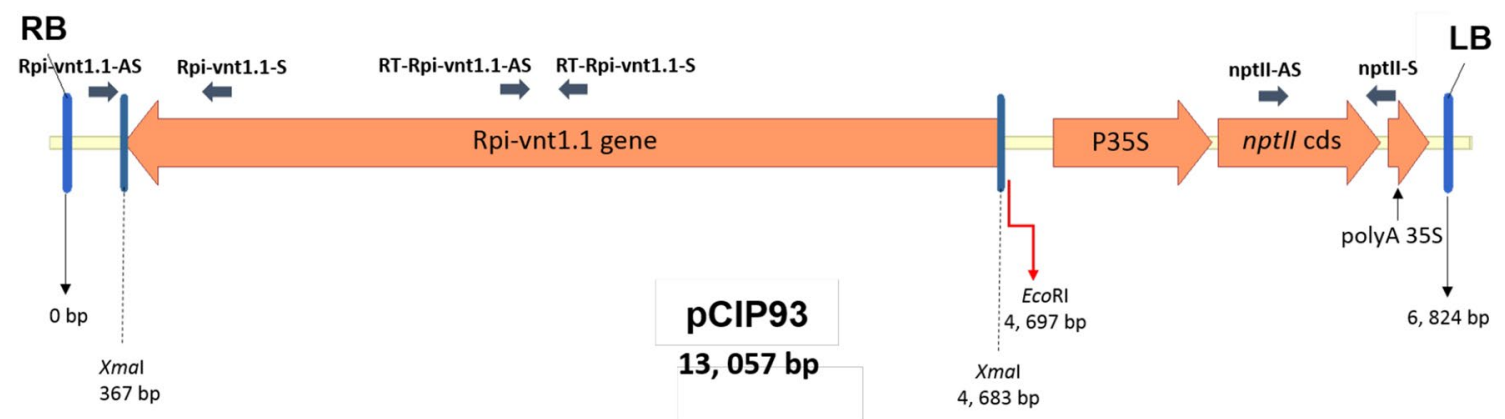

Fig. 1 Schematic representation of the T-DNA region of the binary vector pCIP93. From left to right: RB is the right border; XmaI and $E c o R I$ are restriction sites flanking the Rpi-vnt1.1 gene with $4310 \mathrm{bp}$ $[710,808 \mathrm{bp}$ of native promoter, $256,775 \mathrm{bp}$ of coding sequence and $925 \mathrm{bp}$ of bearing comprising the poly-adenylation signal sequence] indicated by dotted line and the red arrow. P35S is the promoter sequence from the CaMV35S gene; nptII cds is the neomycin phosphotransferase coding sequence; polyA $35 \mathrm{~S}$ is the poly-adenylation signal sequence of the CaMV35S gene and LB is the left border. The distance of the EcoRI restriction site to the left border indicates the minimum size of the positive band by Southern blotting. Thick grey arrows indicate the positions of PCR primers. (Color figure online) 
(1990). Transgenic events were characterized molecularly by PCR and by Southern blotting.

To amplify a portion of nptII and Rpi-vntl.1 genes by PCR assay, two sets of primers were used: nptII-S: 5' CAG CAA TAT CAC GGG TAG CCA-3', nptII-AS: 5'-GGC TAT TCG GCT ATG ACT GGG-3', and Rpi-vnt1.1-S: 5'-GGT GAT CTC GGC ACT ATT G-3', Rpi-vnt1.1-AS: 5'-CCT CTT CGC TAT TAC GCC-3', producing amplicons of 636 and 511 bp respectively. The PCR reaction components were mixed in a final volume of $15 \mu \mathrm{L}$ with $10.6 \mu \mathrm{L}$ of nuclease-free water, $1.5 \mu \mathrm{L}$ of $10 \times$ PCR buffer (New England Biolabs), $0.3 \mu \mathrm{L}$ of $10 \mathrm{mM}$ dNTPs (Promega), $0.75 \mu \mathrm{L}$ of sense and antisense primers $(5 \mathrm{mM}), 0.0375 \mu \mathrm{L}$ of Taq $5 \mathrm{U} / \mu \mathrm{L}$ (New England Biolabs) and $1 \mu \mathrm{L}$ template DNA (100 ng). PCR tests were performed on Applied Biosystem Thermal Cycler. The PCR protocol consisted of an initial denaturation at $94^{\circ} \mathrm{C}$ for $1 \mathrm{~min}$ followed by 35 cycles $\left(94^{\circ} \mathrm{C}\right.$ for $1 \mathrm{~min}, 55^{\circ} \mathrm{C}$ for $1 \mathrm{~min}, 72^{\circ} \mathrm{C}$ for $1 \mathrm{~min}$ ) and a final extension at $72^{\circ} \mathrm{C}$ for $10 \mathrm{~min}$. PCR products were run on an $1 \%$ agarose gel.

For Southern blotting, genomic DNA was extracted as described by Murray and Thompson (1980), $25 \mu \mathrm{g}$ of total DNA was completely digested with EcoRI, then separated on $0.8 \%$ agarose gel, transferred to the nylon membrane Hybond ${ }^{\mathrm{m}-} \mathrm{N}^{+}$and covalently linked by UV (Southern Stratalinker 2400). The probe was amplified from pCIP93 using the primers nptII-S and nptII-AS using the PCR DIG Probe Synthesis kit (Roche). The membrane was hybridized with the denatured DIG probe at $65^{\circ} \mathrm{C}$ for $16 \mathrm{~h}$. The hybridized membrane was washed twice in $2 \times$ saline sodium citrate and $0.1 \%$ dodecyl sodium sulfate for $15 \mathrm{~min}$. Southern blot bands were detected using the DIG Luminescent Detection Kit (Roche).

\section{Resistance test}

Resistance tests were carried out in the confined biosafety greenhouse. The resistant controls were $S$. bulbocastanum SOLblbxblb (CIP763887) and a potato genotype, LBr40 (CIP387164.4), which consistently shows high levels of resistance in the field in Peru. The untransformed variety Desiree (CIP800048), and the variety Yungay (CIP720064) were used as susceptible controls. Control and transgenic plants were acclimatized to greenhouse conditions as follows. Twelve in vitro plantlets per plant were placed in six small Jiffy-7 substrate disks (Jiffy Products International BV) for 15 days. Each Jiffy-7 plantlet was then transplanted to a plastic pot with substrate PRO-MIX (Premier Tech Horticulture); there were six pots per transgenic event. Each plant was irrigated weekly directly into the substrate. After 4 months, small tubers of these plants belonging to the first vegetative generation were harvested. After sprouting, the small tubers were planted to produce the plants used in the resistance bio-assay. Forty-five-day old control and transgenic plants were then inoculated by spraying whole plants until run-off with the suspension of 3000 sporangia/mL. Each plant was covered with a plastic bag to create an extremely humid microclimate at $17-18^{\circ} \mathrm{C}$. Disease severity readings were taken on the fifth day after infection by visual inspection by measuring the percentage of damaged area.

\section{Quantification of the Rpi-vnt1.1 gene expression}

Gene expression was estimated using real-time quantitative PCR (RTqPCR) technique as follows. Three replicates per resistant transgenic event (A, B, and C) were used. Leaves were collected at four time points: (1) before inoculation (prei), (2) 1 day (1 dai), (3) 3 days (3 dai) and (4) 5 days (5 dai) after inoculation, and flash frozen in liquid nitrogen. The total RNA was extracted using RNAeasy Plant mini kit (Qiagen) and converted to cDNA using the Superscript III First-Strand kit Synthesis System for RT-PCR (Invitrogen) and Oligo dT following the manufacturer's protocol. The expression of the Rpi-vntl.1 gene was analyzed using primers RT-Rpi-vnt1.1-S: 5'-GGT AAG GTA TTG GCT CTG-3', RT-Rpi-vnt1.1-AS: 5'-CTT CTC AGC AAT CCA CAT A-3 ' designed using AlleleID 7 (Premier Biosoft), producing an amplicon of $132 \mathrm{bp}$ and normalized to the elongation factor efl $\alpha$ (Nicot et al. 2005). Primer efficiency was determined as described by Pfaffl et al. (2002). The RTqPCR reaction was prepared in a total volume of $10 \mu \mathrm{L}$ as follows: $0.2 \mu \mathrm{L}$ of nuclease-free water, $5 \mu \mathrm{L}$ of SYBR Green Super mix-Applied Biosystem $(2 \times$, final concentration), $0.4 \mu \mathrm{L}$ of each primer $(0.8 \mu \mathrm{M}$, final concentration), $4 \mu \mathrm{L}$ of cDNA template $(50 \mathrm{ng}$ ). The RTqPCR assay started with an initial denaturation at $95^{\circ} \mathrm{C}$ for 10 min followed by 40 cycles $\left(94^{\circ} \mathrm{C}\right.$ for $10 \mathrm{~s}, 55^{\circ} \mathrm{C}$ for $30 \mathrm{~s}, 60^{\circ} \mathrm{C}$ for $\left.1 \mathrm{~min}\right)$. The melting temperature was recorded at $95^{\circ} \mathrm{C}$ for $15 \mathrm{~s}$, $60^{\circ} \mathrm{C}$ for $1 \mathrm{~min}$ and $95^{\circ} \mathrm{C}$ for $15 \mathrm{~s}$. The data was analyzed using REST 2009 (http://rest.gene-quantification.info/). A two-way ANOVA followed by Dunnett's multiple comparison test was used to establish significant differences in relative expression of the Rpi-vnt1.1 gene between the transgenic events at pre-infection stage. The statistical program 6 GraphPad Prism was used (GraphPad Software, Inc.).

\section{Avr-vnt1 gene expression}

Avirulence gene expression was estimated using reverse transcribed PCR (RT-PCR). The infected leaves of the transgenic events and control plants were collected at 3 days after inoculation from the same experiment that was used to estimate the Rpi-vnt1.1 expression. The total RNA was extracted using TRIzol (Invitrogen), and $1 \mu \mathrm{g}$ of total RNA was utilized for cDNA synthesis using oligo dT 
(SuperScriptIII-Invitrogen), as indicated by the manufacturer. The expression of the Avr-vntl gene was analyzed using the primers Avr-vnt1-SP-S: 5'-GTA ACG ACC CCG ACC AAG TT-3' and Avr-vnt1-SP-AS: 5'-TCA AGC TCT AAT AGG ATC AAG C-3' (Pel 2010). The Avr3a gene was used as a control and was amplified using primers Avr3aS: 5'-ATG TGG CTG CGT TGA CGG AGA-3' (Pel 2010) and Avr3a-AS: 5'-TTT GCG CCT TGC GTC TTG CG-3'. The RT-PCR reaction in total volume of $15 \mu \mathrm{L}$ was made of $9.75 \mu \mathrm{L}$ nuclease-free water, $0.45 \mu \mathrm{L} \mathrm{MgCl}_{2}(50 \mathrm{mM})$, $0.6 \mu \mathrm{L}$ dNTPs $(5 \mathrm{mM}$ each), $1.5 \mu \mathrm{L} 10 \times$ buffer, $0.2 \mu \mathrm{L}$ of Platinum Taq Polymerase (5 U) (Invitrogen), $0.75 \mu \mathrm{L}$ of each primer $(10 \mu \mathrm{M})$, and $1 \mu \mathrm{L}$ of cDNA template. The following PCR program was used: $94^{\circ} \mathrm{C}$ for $3 \mathrm{~min}, 94^{\circ} \mathrm{C}$ for $30 \mathrm{~s}, 60^{\circ} \mathrm{C}$ for $30 \mathrm{~s}, 72^{\circ} \mathrm{C}$ for $30 \mathrm{~s}$, during 35 cycles, and $72{ }^{\circ} \mathrm{C}$ for $5 \mathrm{~min}$.

\section{Results}

\section{Identification of LB resistant transgenic events}

From 829 agro-infected internodes, we regenerated 111 putative transformed shoots, of which 76 were confirmed to be highly resistant to kanamycin. Sixty-two of the 76 shoots were confirmed true transgenic events by PCR amplification of the nptII and Rpi-vntl.1 genes. This represents a transformation efficiency of $7.5 \%$. Fifty-two out of the 62 transgenic events were first inoculated with the isolate POX067, while 27 were subsequently inoculated with isolate POX109. Five transgenic events [2, 3, 13, 22, 55] and the resistant genotype LBr-40 presented damage below $20 \%$ to both isolates and are referred to as resistant hereafter (Fig. 2).

\section{Induction of Rpi-vnt1.1 gene in the transgenic events during infection}

The relative expression of the Rpi-vnt1.1 gene (PCR efficiency 99.3\%) in the transgenic events was normalized with the efl $\alpha$ gene (PCR efficiency 107.4\%). All five resistant transgenic events were characterized under infection by both isolates. The pre-inoculation expression level was slightly variable among the five resistant transgenic events but these differences were not significant as they fluctuated between the two isolate assays. The pre-inoculation expression level was, therefore, taken for each event for relative comparison. The kinetic of Rpi-vntl.1 gene expression for all five resistant events show a clear induction response to inoculation starting on day 1 for most of the samples (Fig. 3). Although great care was given to using leaves of similar sizes and physiological conditions, we hypothesize that the differences in the timing of the induction of the Rpi-vnt1.1 gene expression are due to variable leaf area colonized by $P$. infestans hyphae. When the expression data of the five resistant events were averaged, the timepoint response was very similar for both isolates with an

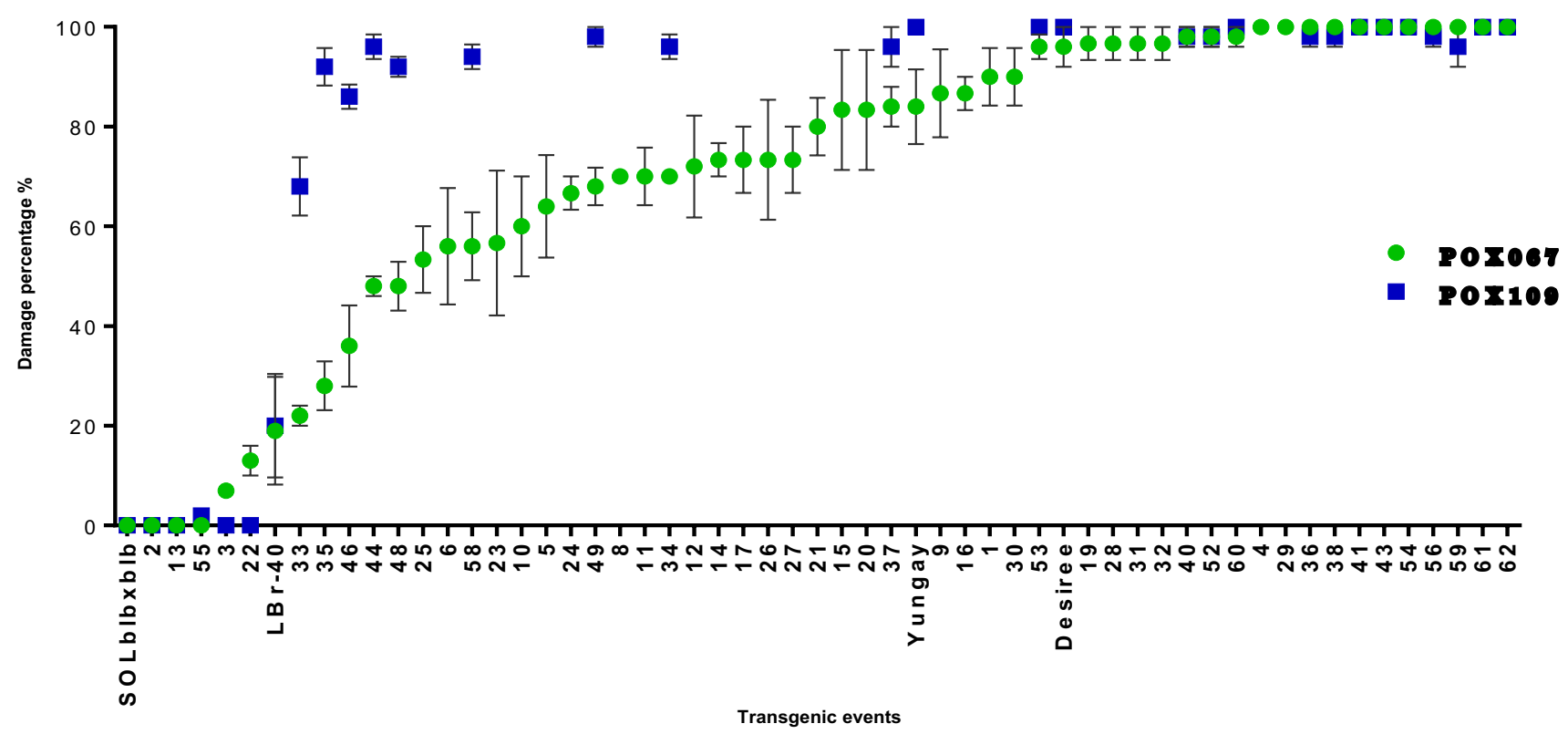

Fig. 2 Resistance to $P$. infestans of Desiree transgenic events bearing the Rpi-vnt1.1 gene using a whole-plant bio-assay. Percentage leaf damage with $P$. infestans isolates POX067 and POX109 are repre- sented by triangle solid dots and square dots, respectively. The varieties Desiree and Yungay were used as susceptible controls, whereas SOLblbxblb and $\mathrm{LBr}-40$ were used as resistant controls 

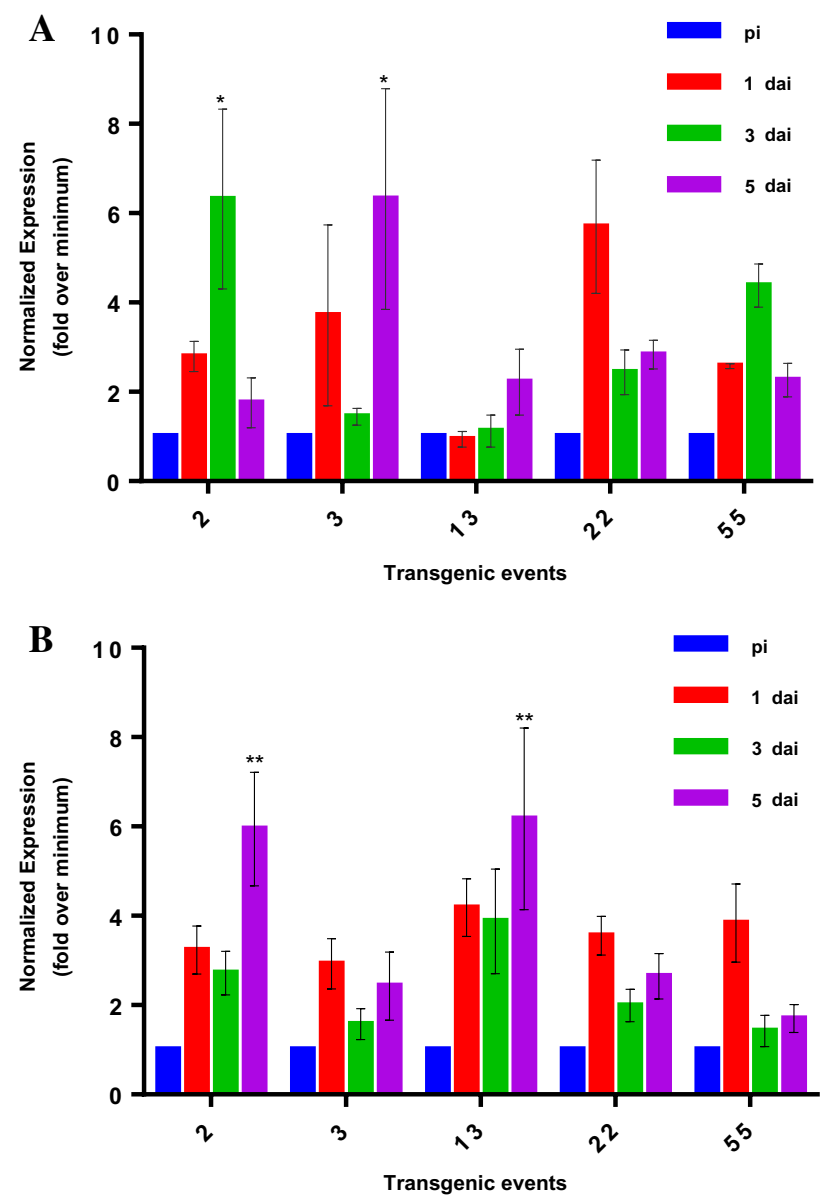

Fig. 3 Normalized expression of the Rpi-vnt1.1 gene in the five resistant transgenic events infected with $P$. infestans isolates POX067 (a) and POX109 (b): pre-inoculation stage values of each event were taken as the baseline expression value for comparisons. The different stages are pi (pre-inoculation), 1 dai (first day after inoculation), 3 dai (third day after inoculation) and 5 dai (fifth days after inoculation), error bars indicate standard error of the mean. * and ** represent significance levels, $\mathrm{p}<0.1$ and $\mathrm{p}<0.01$, respectively

induction of at least two-fold 1 day after inoculation, followed by a slow gradual decline (Fig. 4).

\section{Avr-vnt1 expression in both EC-1 isolates}

Semi-quantitative estimation of effector gene expression showed that, as expected, both EC-1 isolates expressed the Avr3a gene, indicating a successful infection of plant cells at 3 days after inoculation. Similarly, the presence of an RT-PCR band of expected size was detected for the Avrvntl gene in all interactions suggesting that all transgenic events expressing the Rpi-vntl.1 gene should be resistant to both isolates (POX067 and POX109) tested (Fig. 5). This was observed even for the transgenic events with no lesions (2, 13, and 55) indicating that the Rpi-vntl.1-mediated resistance occurs after penetration.
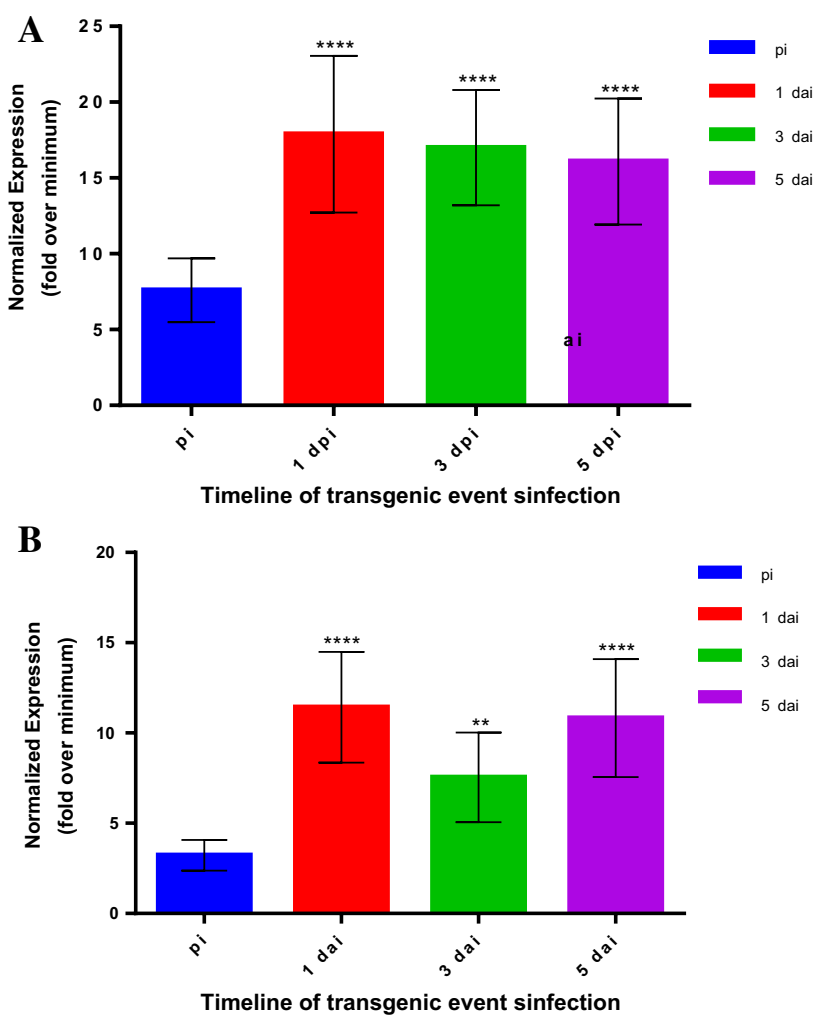

Fig. 4 Average normalized expression of the Rpi-vnt1.1 gene of five resistant transgenic potato events before inoculation and during infection with P. infestans isolates POX067 (a) and POX109 (b). Timepoints are the same as Fig. 3; error bars indicate standard error of the mean. $* *$ and $* * * *$ represent significance levels of $\mathrm{p}<0.01$ and $\mathrm{p}<0.0001$ respectively

\section{Copy number of the Rpi-vnt1.1 gene in the resistant transgenic events}

The southern blot test provided an estimate of transgene copy number. Four of the most resistant transgenic events were found to have a single copy, while three had with multiple copies (Fig. 6). There was no correlation between the number of copies and Rpi-vnt1.1-gene expression or with level of resistance to the pathogen.

\section{Discussion}

The Rpi-vnt1.1 resistance gene originating from the South American species $S$. venturii was recently introduced into a potato variety for commercial release in the US and is generally seen as a promising new source of late blight resistance because it was shown to confer resistance against several highly virulent European strain of $P$. infestans (Foster et al. 2009; Pel et al. 2009; Jones et al. 2014; Clark et al. 2014). However, two observations can be made in relation to the expected durability of resistance. Firstly, the 
A

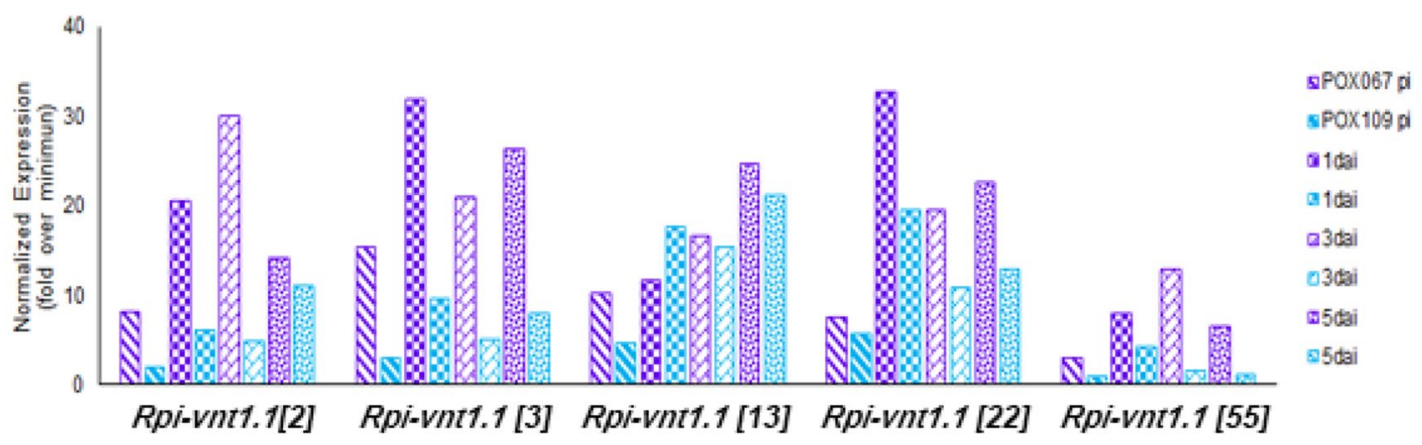

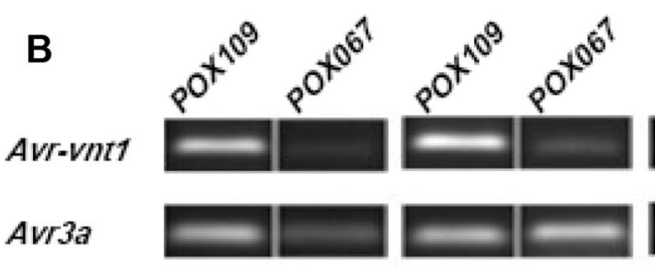

Fig. 5 a Relative expression of Rpi-vnt1.1 in transgenic plants of potato variety Desiree [Rpi-vnt1] 2,3,13,22,55 at 0 days pre-inoculation (pi) and 1, 3 and 5 days after inoculation (dai). b Expression

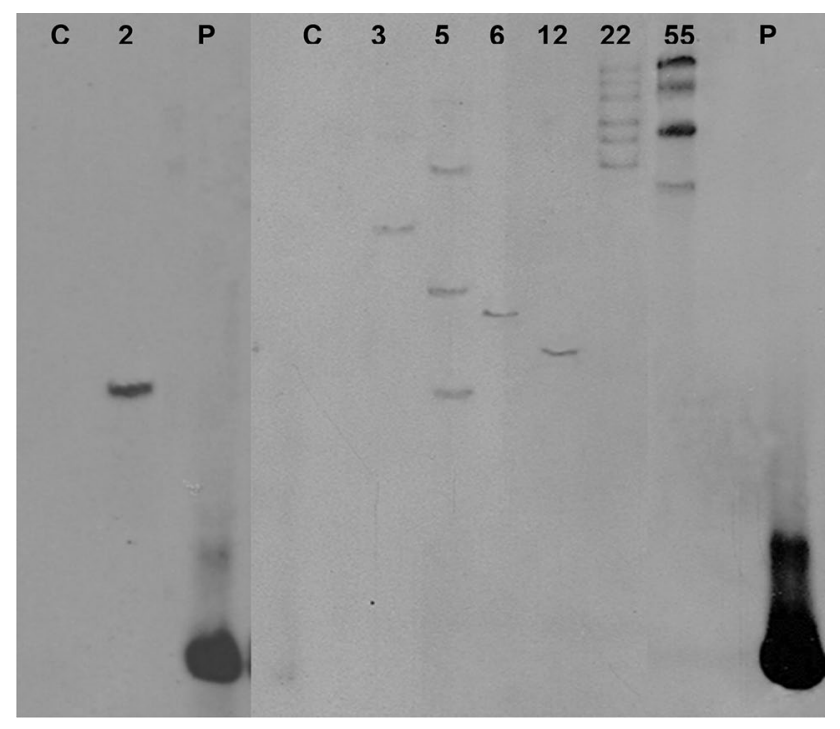

Fig. 6 Copy number analysis of the Rpi-vnt1.1 gene in potato variety Desiree transgenic events. Southern hybridization analysis of genomic DNA from resistant transgenic events with Rpi-vnt1.1 gene. $C$ is the untransformed plant DNA from Desiree variety; numbers are each of the resistant transgenic events; and $P$ is probe from nptII gene with a size of $597 \mathrm{bp}$

3-year field trials in the UK demonstrated that the Rpivntl.1 gene provided excellent resistance during the active growth period but decreased as the plants were senescing (Jones et al. 2014). Although yield was unaffected, harvested tubers, likely contaminated with $P$. infestans, may lose quality upon storage which is common in temperate regions. Secondly, as noted one $P$. infestans isolate of the of avirulence genes Avr-vnt1 and Avr3a as their control of virulencia infection $A v r 3 a$ in the transgenic events mentioned above at 3 dai

EC-1 lineage (the only one tested from the lineage) was reported to overcome the resistance conferred by this gene (Foster et al. 2009; Pel et al. 2009). The pathogenicity of the isolate was attributed to the silencing of the Avr-vnt1 gene (Pel 2010). The Avr-vntl gene silencing in EC-1 was suggested to be caused by either epigenetic or post-transcriptional gene silencing (PTGS). Another P. infestans isolate from Poland was reported to be virulent on potato breeding lines bearing the Rpi-phul gene which is identical to Rpi-vnt1.1 gene (Stefańczyk et al. 2017). Similar to the results by Pel (2010), the Avr-vntl transcripts were not detectable on the first two days but were on day 3 of the compatible interaction with potato plant containing Rpiphul gene and detected at very low level on all days post inoculation in compatible interaction with a potato line that doesn't contain the Rpi-phul gene (Stefańczyk et al. 2017). Studies concerning the expression of $R$ gene show varied levels of induction depending on the potato genotype and $P$. infestans isolate used. In an incompatible interaction, the Rpi-phul gene expression was shown to be induced 1 day after inoculation in diploid breeding lines but not in tetraploid breeding lines bearing this gene (Śliwka et al. 2013), while other potato lines show no induction during incompatible interaction but show a late induction (day 5) during a compatible interaction (Stefańczyk et al. 2017). Hence, the Rpi-vntl.1 (or Rpi-phul) / Avr-vntl gene expression ratio seems to depend on the specific interaction between the potato genotype and the $P$. infestans strain.

We selected five transgenic events with the Rpi-vnt1.1 gene from the potato variety 'Desiree' that are extremely resistant to two isolates of the EC-1 clonal lineage of $P$. 
infestans and investigated $R$ and $A v r$ gene expression to improve our understanding of the stability of the resistance conferred by the Rpi-vntl.1 gene in transgenic potato. Our finding of EC-1 resistant transgenic events with Rpi-vntl.1 gene was unexpected based on the $R / A v r$ gene model and previous observations by Foster et al. (2009) and Pel (2010). The EC-1 strains may differ in their virulence due to several factors. Experimental conditions to prepare the $P$. infestans inoculum could reset expression of Avr-vntl gene in the case of an epigenetic control. Foster et al. (2009) and Pel et al. (2009) used Rye $\mathrm{B}$ agar and high inoculum concentrations $(50,000$ sporangia/mL) whereas we used potato tuber slices and less concentrated inoculum (3000 sporangia/mL). The EC-1 lineage was recently further characterized in Ecuador and found to present genetic and virulence variation (Delgado et al. 2013). Therefore, it is plausible that the EC-1 strain used by Foster et al. (2009) and Pel (2010) differs in virulence from the EC-1 strains used in our study. The Avr-vntl gene expression was detected in the Peruvian EC-1 isolates POX067 and POX109 when inoculated on transgenic resistant plants and on the susceptible cultivar Yungay, contrasting with the observed absence of expression of Avr-vntl in the EC-1 strains used by Foster et al. (2009) and Pel (2010). Interestingly, in a previous study we found that Avr-vntl was expressed in POX067 but not expressed in the POX109 isolate in a compatible interaction using the transcript quantification technique RNAseq (Izarra and Lindqvist-Kreuze 2016). Interestingly, Avr$v n t 1$ in POX109 decreases 3 days after inoculation (Izarra et al. 2014). Stefańczyk et al. (2017) did not detect Avrvntl expression in virulent strains infecting breeding lines with the Rpi-phul gene but detected it when the same strains were infecting a breeding line without the Rpiphul gene. Across all these studies, including ours, Avrvntl gene expression has been very low in the virulent isolates and no clear evidence exists yet as to whether its detection in potato plants without the Rpi-vntl.1 or Rpiphul genes reflect a real change in expression. Oomycete pathogens can evade recognition by silencing $A v r$ gene which could be the explanation of the EC-1 virulence (Qutob et al. 2009, 2013; Vetukuri et al. 2013; Na et al. 2014). Sub-clonal variation in virulence is typical for $P$. infestans such that isolates belonging to the same clonal lineage have different virulence patterns. In controlled laboratory experiments a continuous change during asexual reproduction was observed resulting in progenies with either loss or gain of virulence, of which some were drastic, resulting in completely different virulence patterns (Samen et al. 2003). These changes are unlikely a result of mutations, but rather of epialleles that may exist in various transcriptional states. Further research is needed to study the expression pattern of Avr-vntl in naturally infected plants vs. after laboratory inoculation to understand the on-off switching mechanisms of this avirulence gene.

The expression of the Rpi-vnt1.1 gene in the five resistant transgenic events was also investigated over 5 days after inoculation. The pre-inoculation expression was the lowest for all events in comparisons with the others time points followed by an increased expression already at first day post-infection for all transgenic events tested with both isolates. The first $24 \mathrm{~h}$ after the infection with $P$. infestans are crucial to determining resistance levels in plants and avoid development and spread of the pathogen. We observed a two-fold increase of expression of the Rpi-vnt1.1 gene within the first $24 \mathrm{~h}$ which is consistent with the $R B$ gene expression correlation with $P$. infestans resistance (Kramer et al. 2009). Other $R$ genes have been shown to confer resistance to $P$. infestans strains based on the $R / A v r$ ratio (Pel 2010). Due to the low level of expression of Avr-vnt1 or for technical reasons, Pel (2010) could not establish such a relationship for Rpi-vnt1.1, as was also reported by Stefańczyk et al. (2017) and by us in this study. Rpi-vnt1.1 transcript level may be higher when the gene is in a highly transcriptionally active region of the genome, or if the gene is present in numerous copies (Bradeen et al. 2009). Indeed, our observation that the disease scores vary continuously from fully susceptible to highly resistance for the 52 transgenic events tested is likely related to the amount of $R p i$ vnt1.1 transcripts which could be gene expression (positional effect) and/or number of copies of the Rpi-vnt1.1 gene. We did not assess gene expression of the 52 transgenic events but four of the five resistant transgenic events contained a single copy of the transgene and all exhibited a similar pattern of low constitutive expression and induction post pathogen inoculation. Hence, the observation of 5 resistant events out of 52 is more likely due to level of gene expression than Rpi-vnt1.1 gene copy number.

In conclusion, we have shown here that resistant transgenic events could be obtained against strains of $P$. infestans previously considered as virulent using the cognate $R$ gene. Resistance to the isolates which presented a very low level of expression of the Avr gene was characterized by early induction and steady state expression of the $R$ gene in the resistant transgenic events. The existence of virulent isolates like EC-1 does not preclude the development of resistant varieties with the Rpi-vnt1.1 gene as we have demonstrated here. However, the pathogen population must be carefully investigated for the presence of virulent isolates which, even in low frequency, can rapidly be selected and result in partial or total loss of this $R$-gene-mediated resistance. In addition, the apparent ability of $P$. infestans to switch on and off its Avr-vntl gene may contribute to loss of resistance of the Rpi-vnt1.1 transgenic variety. Due to the virulence diversity within clonal lineages and 
the evolution capacity of $P$. infestans, the stacking of the $R p i$-vnt1.1 gene together with other $R$ genes, such as the Rpi-blb2 gene, will maximize the chance of a long-lasting resistance to late blight in potato (Orbegozo et al. 2016).

Acknowledgements This research was supported by the United States Agency for International Development (USAID) and recently by the 2Blades foundation.

Author Contributions MLR, CR developed the transgenic potato plants and the Rpi-vnt1.1 gene expression analyses under direction from JK. MI developed Avr-vnt1 expression analyses under direction from HLK. SG performed the whole-plant bioassays under direction of GF. All authors contributed to the manuscript development. MG designed the experiment and lead the overall research.

\section{Compliance with ethical standards}

Conflict of interest All authors declare that they have no conflict of interest.

Open Access This article is distributed under the terms of the Creative Commons Attribution 4.0 International License (http:// creativecommons.org/licenses/by/4.0/), which permits unrestricted use, distribution, and reproduction in any medium, provided you give appropriate credit to the original author(s) and the source, provide a link to the Creative Commons license, and indicate if changes were made.

\section{References}

Bradeen JM, Iorizzo M, Mollov DS, Raasch J, Kramer LC, Millett BP, Austin-Phillips S, Jiang J, Carputo D(2009) Higher copy numbers of the potato $R B$ transgene correspond to enhanced transcript and late blight resistance levels. Mol Plant-Microbe Interact 22:437-446

Camire ME, Kubow S, Donnelly DJ (2009) Potatoes and human health. Crit Rev Food Sci Nutr 49:823-840

Clark P, Habig J, Ye J, Collinge S (2014) Petition for determination of nonregulated status for Innate ${ }^{\mathrm{TM}}$ potatoes with late blight resistance, low acrylamide potential, reduced black spot, and lowered reducing sugars: Russet Burbank event W8. JR Simplot Company Petition JRS01 (USDA Petition 14-093-01p)

Delgado R, Monteros-Altamirano A, Li Y, Visser R, Lee T, Vosman B (2013) Large subclonal variation in Phytophthora infestans populations associated with Ecuadorian potato landraces. Plant Pathol 62:1081-1088

Doyle JJ, Doyle J (1990) Isolation of plant DNA from fresh tissue. Focus 12:13-15

FAO (2014) FAOSTAT crop data http://www.fao.org/faostat/en/\#data/ QC. Accessed 10 Jan 2017

Forbes GA, Escobar XC, Ayala CC, Revelo J, Ordoñez ME, Fry BA et al (1997) Population genetic structure of Phytophthora infestans in Ecuador. Phytopathol 87:375-380

Forbes GA, Goodwin SB, Drenth A, Oyarzun P, Ordoñez ME, Fry WE (1998) A global marker database for Phytophthora infestans. Plant Dis 82:811-818

Foster SJ, Park T-H, Pel M, Brigneti G, Śliwka J, Jagger L et al (2009) Rpi-vnt1.1, a Tm-22 homolog from Solanum venturii, confers resistance to potato late blight. Mol Plant-Microbe Interact 22:589-600
Fry W (2008) Phytophthora infestans: the plant (and R gene) destroyer. Mol Plant Pathol 9:385-402

Fry W, Birch P, Judelson H, Grünwald NJ, Danies G, Everts KL et al (2015) Five reasons to consider Phytophthora infestans a re-emerging pathogen. Phytopathol 105:966-981

Gilroy EM, Breen S, Whisson SC, Squires J, Hein I, Kaczmarek $M$ et al (2011) Presence/absence, differential expression and sequence polymorphisms between PiAVR2 and PiAVR2-like in Phytophthora infestans determine virulence on R2 plants. New Phytol 191:763-776

Haverkort A, Struik P (2015) Yield levels of potato crops: recent achievements and future prospects. Field Crops Res 182:76-85

Haverkort A, Boonekamp P, Hutten R, Jacobsen E, Lotz L, Kessel $\mathrm{G}$ et al (2008) Societal costs of late blight in potato and prospects of durable resistance through cisgenic modification. Potato Res 51:47-57

Haverkort A, Struik P, Visser R, Jacobsen E (2009) Applied biotechnology to combat late blight in potato caused by Phytophthora infestans. Potato Res 52:249-264

Hood EE, Gelvin SB, Melchers LS, Hoekema A (1993) NewAgrobacterium helper plasmids for gene transfer to plants. Transgenic Res 2:208-218

Izarra M, Lindqvist-Kreuze H (2016) Expresión de efectores RXLR en el linaje clonal EC-1 de Phytophthora infestans en Perú. Rev Peru Biol 23:293-300

Izarra M, Perez W, Lindqvist-Kreuze H (2014) Identificación de efectores de Phytophthora infestans expresados diferencialmente en el linaje clonal EC-1. ALAP Bogotá, Poster publication, p 126

Jones JD, Dangl JL (2006) The plant immune system. Nature 444:323-329

Jones JD, Witek K, Verweij W, Jupe F, Cooke D, Dorling S et al (2014) Elevating crop disease resistance with cloned genes. Philos Trans R Soc London B 369:20130087

Kramer LC, Choudoir MJ, Wielgus SM, Bhaskar PB, Jiang J (2009) Correlation between transcript abundance of the $R B$ gene and the level of the $R B$-mediated late blight resistance in potato. Mol Plant-Microbe Interact 22:447-455

Medina-Bolívar F, Cramer C (2004) Production of recombinant proteins by hairy roots cultured in plastic sleeve bioreactors. Methods Mol Biol 267:351-363

Na R, Yu D, Chapman BP, Zhang Y, Kuflu K, Austin R et al (2014) Genome re-sequencing and functional analysis places the Phytophthora sojae Avirulence genes Avrlc and Avrla in a tandem repeat at a single locus. PloS ONE 9:e89738

Nicot N, Hausman J-F, Hoffmann L, Evers D (2005) Housekeeping gene selection for real-time RT-PCR normalization in potato during biotic and abiotic stress. J Exp Bot 56:2907-2914

Nunn N, Qian N (2011) The potato's contribution to population and urbanization: evidence from a historical experiment. Q J Econ 126:593-650

Orbegozo J, Roman ML, Rivera C, Gamboa S, Tovar JC, Forbes GA, Lindqvist-Kreuze H, Kreuze JF, Ghislain M (2016) Rpi-blb2 gene from Solanum bulbocastanum confers extreme resistance to late blight disease in potato. Plant Cell Tissue Org 125:269-281

Pel MA (2010) Mapping, isolation and characterization of genes responsible for late blight resistance in potato. $\mathrm{PhD}$ thesis, Wageningen University \& Research

Pel MA, Foster SJ, Park TH, Rietman H, van Arkel G, Jones JD, Van Eck HJ, Jacobsen E, Visser RG, Van der Vossen EA (2009) Mapping and cloning of late blight resistance genes from Solanum venturii using an interspecific candidate gene approach. Mol Plant-Microbe Interact 22:601-615

Perez WG, Gamboa JS, Falcon YV, Coca M, Raymundo RM, Nelson RJ (2001) Genetic structure of Peruvian populations of Phytophthora infestans. Phytopathol 91:956-965 
Pfaffl MW, Horgan GW, Dempfle L (2002) Relative expression software tool $\left(\mathrm{REST}^{\odot}\right)$ for group-wise comparison and statistical analysis of relative expression results in real-time PCR. Nucleic Acids Res 30:e36-e36

Qutob D, Tedman-Jones J, Dong S, Kuflu K, Pham H, Wang Y et al (2009) Copy number variation and transcriptional polymorphisms of Phytophthora sojae RXLR effector genes Avrla and Avr3a. PloS ONE 4:e5066

Qutob D, Chapman BP, Gijzen M (2013) Transgenerational gene silencing causes gain of virulence in a plant pathogen. Nat Commun 4:1349

Rodewald J, Trognitz B (2013) Solanum resistance genes against Phytophthora infestans and their corresponding avirulence genes. Mol Plant Pathol 14:740-757

Samen FA, Secor GA, Gudmestad NC (2003) Variability in virulence among asexual progenies of Phytophthora infestans. Phytopathol 93:293-304

Śliwka J, Świątek M, Tomczyńska I, Stefańczyk E, Chmielarz M, Zimnoch-Guzowska E (2013) Influence of genetic background and plant age on expression of the potato late blight resistance gene Rpi-phul during incompatible interactions with Phytophthora infestans. Plant Pathol 62:1072-1080

Spooner DM, Gavrilenko T, Jansky SH, Ovchinnikova A, Krylova E, Knapp S et al (2010) Ecogeography of ploidy variation in cultivated potato (Solanum sect Petota). Am J Bot 97:2049-2060

Stefańczyk E, Sobkowiak S, Brylińska M, Śliwka J (2017) Expression of the potato late blight resistance gene Rpi-phul and Phytophthora infestans effectors in the compatible and incompatible interactions in potato. Phytopathol 107:740-748

Vetukuri RR, Åsman AK, Jahan SN, Avrova AO, Whisson SC, Dixelius C (2013) Phenotypic diversification by gene silencing in Phytophthora plant pathogens. Commun Integr Biol 6:e25890

Villamon FG, Spooner D, Orrillo M, Mihovilovich E, Perez W, Bonierbale M (2005) Late blight resistance linkages in a novel cross of the wild potato species Solanum paucissectum (series Piurana). Theor Appl Genet 111:1201-1214

Vleeshouwers VG, Raffaele S, Vossen JH, Champouret N, Oliva $\mathrm{R}$, Segretin ME et al (2011) Understanding and exploiting late blight resistance in the age of effectors. Annu Rev Phytopathol 49:507-531 